\title{
Production of Tilapia (Oreochromis niloticus) Fingerling in Hapa Using Swim-up Fry Involving Women in the Haor Region of Bangladesh
}

\author{
Mrityunjoy Kunda ${ }^{1}$, Ahmed Harun-Al-Rashid ${ }^{1}$, Farjana Morshed ${ }^{1}$, Mohammed \\ Ariful Islam ${ }^{1}$ and Sabuj Kanti Mazumder ${ }^{1,2}$ \\ ${ }^{I}$ Department of Aquatic Resource management, Faculty of Fisheries, Sylhet Agricultural University, Sylhet- \\ 3100 \\ ${ }^{2}$ Department of Marine Science, School of Environment and Natural Resource Sciences, University Kebangsaan \\ Malaysia, Bangi, Selangor, 43600, Malaysia
}

\begin{abstract}
The inadequate supply of tilapia seed mostly fingerling which consider as the secured stock because of lower mortality rate is considered as one of the major present constraints to the development of the culture industry in annual flooded region of haor in Bangladesh. The floating bamboo net-hapa nursery system was observed to be very efficient in the mass production of tilapia fingerlings at haor water body in Sunamganj district, Bangladesh. This system was therefore, recommended for small-scale (artisanal) commercial operators consisting of fishermen families mostly involvement of women in order to uphold their socio economic contribution and hasten development of haor communities. The research was conducted by three treatments with three replicates each. It was found that treatment I showing stocking density of $750 / \mathrm{m}^{2}$ with FCR and SGR were $1.14 \pm 0.038^{a}$ and $10.55 \pm 0.103^{a}$ respectively was found to be the most favorable treatment among all. But while considering the cost benefit ratio treatment II found better for commercial aquaculture as the survival rate was higher in treatment II. Besides the treatment with moderate stocking rate of $900 / \mathrm{m}^{2}$ found to be most profitable with Tk. $793.12 \pm 67.73^{b}$ while in treatment I (stocking density $750 / \mathrm{m}^{2}$ ) and treatment III (stocking density 1050/ $\mathrm{m}^{2}$ ) the net profit were $582.45 \pm S D 88.75^{a}$ and $T k .655 .04 \pm 51.76^{a b}$, respectively. As in the commercial production the increasing in stocking density also increase net profit with the same unit area and resources. But in small scale farming like tilapia fingerling production not only profit but also investment capability need to be take into consideration. The cost-benefit ratio found in this study showed that in treatment I, II and III the benefit-cost ratio were 2.17:1, 2.36:1 and 1.99:1 respectively which indicate a moderate stocking density of treatment II is most profitable. It was emphasized that the operational and managerial skills of the culture operators in fingerling production account largely to the production cost minimizing and profitability as well.
\end{abstract}

Keywords: Tilapia, Fingerling, Hapa, Women and Haor

\section{Introduction}

Haor region is naturally a fishery resourceful area of Bangladesh. People in the haor region especially the fisher community are habituated to catch fish from the nature not to culture fish in ponds or open water. Due to decreasing trend of fish in the haor, people are getting interest to culture fish in ponds, but still they do not aware about open water aquaculture. One of the major constraints of fish culture in haor region is unavailability of quality fish seed. To meet up the growing demand of quality fish seed fingerling rearing in hapa can be one of the good options, especially in the open water area. Because open water aquaculture has not yet been introduced in the open water of haor region. Moreover, women of the households can be involved to produce fish fingerling using hapa or cage in the haor region. With this view the present study has been under taken to produce tilapia fingerling using hapa which can be a supplementary income for the households as well as supply of quality tilapia seed for the grow-out farming.

Women living in the haors are particularly disadvantaged and vulnerable. They have less access to education, health services and employment, which in turn contributes to social barriers. In addition specific attention needs to be paid to develop income-generating possibilities for women as an additional important contribution to reducing poverty and gender inequality. The earning woman's own well being is likely to benefit, but it also likely that the proportion of income spent on the well being of children and their education would also increase. Moreover special programs need to be constructed aiming women-headed households, particularly to providing employment to these women and enabling them to develop a fund, which could be subsequently invested in income-earning activities.

Tilapia (Oreochromis niloticus) has a worldwide distribution, originating in the Rift valley lakes of Africa $^{[1]}$. Like all over the world, in Bangladesh the GIFT strains of tilapia are becoming most popular culture 
species. Besides high disease resistance, culture possibility with excessive stocking density, favorable for any kind of water body with suitable farming technique make tilapia as a unique species for aquaculture. Unlike others, tilapia seeds supply cannot meet demands as much besides large size seed have much popularity among farmer because of survival rate and fine growth. There are several methods used for fingerling production depending on the culture area, investment, production dimension etc. Among them bamboo net hapa is most favorable both for the open and closed water body. Besides fry collection, monitoring, feeding and also harvesting are much easier in hapa system. Moreover in haor flooding area using hapa for fingerling production is mostly suitable and also cost effective as the hapa produced with nylon net can easily be reused for several times by washing firmly.

Tilapia fingerling production using swim up fry in hoar region can not only ensure sufficient supply of quality seeds in culture potential as a poverty elevation aquaculture tools but also women involvement possibility in tilapia fingerling production in hoar region will reduce gender discrimination by upholding socio economic status of women by the direct surplus in family income which consequently lead them to change social mentality towards them through a feasible and secured way of economic contribution.

Women have little participation in decision-making processes in haor society because of their little economic contribution to the family. Income earning is considered as basis for the power of decision making while women's contribution in the family remains unnoticed and undervalued as unpaid family labor. So also the ownership of assets, including those that the husband gets from the father in- law as dowry, lies with the husband alone. These are may not consider as only a fate of them but instead then are not even know what they can do with asset or how can they contribute economically in a secured way. Taking all the issues into consideration the aims of the study are to introduce hapa nursing system of tilapia in haor region, to produce quality tilapia fingerling using hapa and also seeking a way of women involvement in aquaculture in a suitable means accepted in the socio economic consideration of haor region.

\subsection{Site selection}

\section{Materials and Methods}

Haors are wetlands in the North Eastern part of Bangladesh which physically is a bowl shaped shallow depression. It is a mosaic of wetland habitats including rivers, streams and irrigation canals, large areas of seasonally flooded cultivated plains and hundreds of haors and beels ${ }^{[2]}$. In this research plan the haor region of Bangladesh is aimed as target region and research were performed in the hoar area of Soma Nadi jalmohal area of Derai upazila of Sunamganj district. The study area is located in between $24^{\circ} 39^{\prime}$ and $24^{\circ} 53^{\prime}$ north latitudes and in between $91^{\circ} 10^{\prime}$ and $91^{\circ} 28^{\prime}$ east longitudes between 5 April to 10 June 2014 . Women of the research site were involved for hapa nursing system of tilapia as target population. Livelihoods of more than $80 \%$ population of this area are depended on fishing.

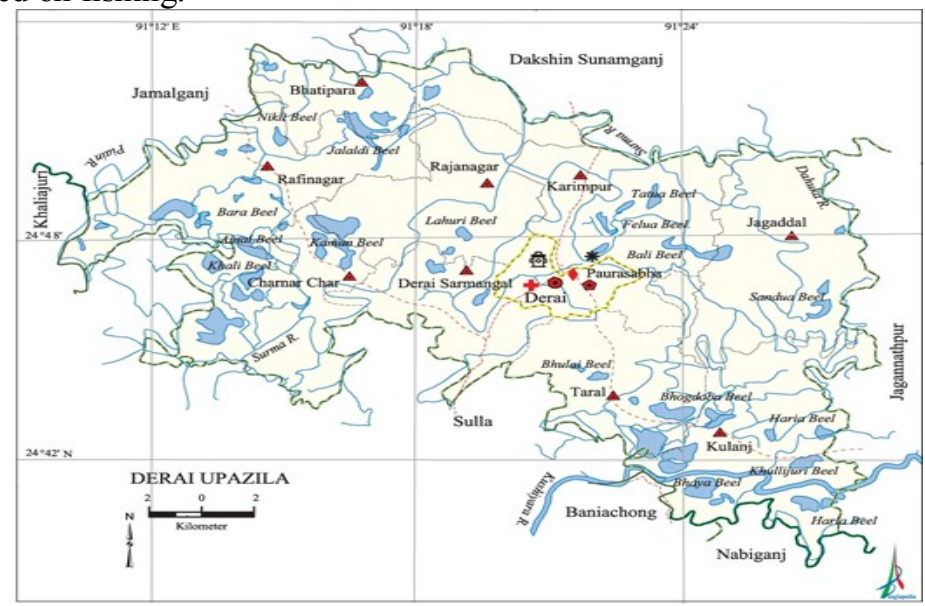

Figure 1. Location of the study site.

\subsection{Research design}

Around $0.0173 \mathrm{~g}$ size tilapia fry were used for hapa nursing with a view to grown up to $3-4 \mathrm{~g}$ size. Each of the hapa was $=4.25 \mathrm{~m} \mathrm{X} 2.75 \mathrm{~m}=11.68 \mathrm{~m}^{2}$ size while height of hapa $=1.35 \mathrm{~m}$. The research was conducted by three treatments with three replicates each. The treatments were depended on stocking density at the rate of $750 / \mathrm{m}^{2}, 900 / \mathrm{m}^{2}$ and $1050 / \mathrm{m}^{2}$ respectively in treatment-I, Treatment-II and Treatment-III. Details of stockings are given in table 1. 
Table 1. Stocking weight, density and number of fry in different treatments.

\begin{tabular}{ccccc}
\hline Treatments & Primary weight & Stocking density & Area of hapa & Total number of fry \\
\hline Treatment I & $0.0173 \mathrm{~g}$ & $750 / \mathrm{m}^{2}$ & $11.68 \mathrm{~m}^{2}$ & 8760 \\
Treatment II & $0.0173 \mathrm{~g}$ & $900 / \mathrm{m}^{2}$ & $11.68 \mathrm{~m}^{2}$ & 10512 \\
Treatment III & $0.0173 \mathrm{~g}$ & $1050 / \mathrm{m}^{2}$ & $11.68 \mathrm{~m}^{2}$ & 12264 \\
\hline
\end{tabular}

\subsection{Hapa making and set-up}

Hapas are constructed with fine meshed nylon net and rope which is sewn together to form a square or rectangular enclosure. Hapa looks like an inverted mosquito net and are often used for fingerling nursing and short time storage of fish fingerling. For this study same size fine meshed hapa was used with length $4.25 \mathrm{~m}$, width $2.75 \mathrm{~m}$ and height $1.35 \mathrm{~m}$. The hapas were fixed with bamboo pole and tied up with rope both upper and lower end of the hapa. Hapa set up completed one week prior to stocking of tilapia fry. To avoid clogging hapas were cleaned once in a week.

\subsection{Stocking of fry}

Tilapia fries were collected from Bismillah Hatchery, Noakhali, Bangladesh where improved germplasm of tilapia has been developed by WorldFish, Bangladesh in collaboration with RFLDC-Noakhali project. During transportation the fry were packed in plastic bag with water and oxygen. The fry will be transported by pick-up van and stocked early in the morning. Before stocking the fry, plastic bags were kept for half an hour inside the hapa to minimize the water temperature as hapa. The fries were transported at night and stocked early in the morning.

\subsection{Feeding}

Feeding was started with commercial nursery feed at 50\% body weight (BW) of fishes and gradually reduced up to $8 \%$ BW. Feeds were spread over the hapa. One third of the feed was applied in the morning 8.00$9.00 \mathrm{hrs}$, one third during 12.00-13.00 hrs and rest of the feed 16.00-17.00 hrs. Feeding rate can be adjusted depending on the requirement of feed. In this study feed is adjusted once in a week.

\subsection{Monitoring and data collection}

Feeding rate were monitored regularly, health condition can be checked after every fifteen days and condition of hapa were checked after every fifteen days whether getting damage or not or excess feed can be accumulated at the bottom of the hapa. Length and weight of 30 individuals were measured and recorded from each of the hapa and it is carrying out every fifteen days interval up to final harvest. Final measurements were taken at the end of the research and total number of fingerling were counted and recorded.

\subsection{Growth performance analysis}

During the experiment batch weight were recorded every fifteen days. A record of the amount of feed fed in grams was also recorded. Every 15 days interval weight $(\mathrm{g})$ length $(\mathrm{cm})$ measurements of randomly collected 30 individuals were taken. The following calculations were made to evaluate fish growth performance:

a) Average weight gain $=$ Mean final fish weight- Mean initial fish weight

b) Specific Growth Rate $(\%$ day $)=\left(\log _{\mathrm{e}} \mathrm{W}_{2}-\log _{\mathrm{e}} \mathrm{W}_{1} \times 100\right) / \mathrm{T}_{2}-\mathrm{T}_{1}$

Where,

$\mathrm{W}_{1}=$ the initial live body weight $(\mathrm{g})$ at time $\mathrm{T}_{1}$ (day)

$\mathrm{W}_{2}=$ the final live body weight $(\mathrm{g})$ at time $\mathrm{T}_{2}$ (day)

c) Survival $(\%)=$ No. of fishes harvested $\times 100 /$ No. of fishes stocked

d) Yield $=$ No. of fish caught $\times$ Average final weight

e) Food Conversion Ratio (FCR) = amount of dry food intake (g)/ Fresh weight gain in fish

\subsection{Cost-return analysis}

A simple cost-return analysis was calculated to determine economic returns of different treatments. The analysis was based on market prices of local market for fish. All other items expressed in Bangladesh taka, BDT (US \$1= BDT 80).

\subsection{Statistical analysis}

All the data collected during experiment were recorded and preserved in computer. The data obtained in the experiment were analyzed statistically using SPSS (version 18.0) statistical software (SPSS Inc., Chicago, USA). Differences were considered significant at an alpha of 0.05 . Means were given with \pm standard deviation (SD). 


\subsection{Survival of tilapia fry}

\section{Results}

The survival of tilapia fry in treatment-I, treatment-II and treatment-III were $71.87,76.22$ and $62.64 \%$, respectively (Figure 2). The survival percentages show significant variations, this might happened due to weakness of transportation and other stresses following the stages of stocking of swim up fry in the treatments or because of stocking density in treatment III. Although several studies related to stocking density did not support direct relation of survival with stocking density.

\subsection{Monthly growth increment}

After initial sampling and stocking the tilapia fry into the treatment hapa, weight were sampled in five random days and compared to see the monthly growth increment (Figure 3). By the following line diagram the sampling shows that at the end of the first month of stocking the growth increment were very slow but almost same among treatments $(0.0173 \mathrm{gm}$ to $0.5 \mathrm{gm})$, which gradually raise to a maximum increment rate by the next month with a significant changes among the treatments. The growth increments significantly increase in treatment-2 $\left(2.94 \pm 0.17^{\mathrm{b}}\right)$ compared to Treatment-3 $\left(2.16 \pm 0.17^{\mathrm{c}}\right)$ while also in treatment-1 $\left(3.7 \pm 0.2^{\mathrm{a}}\right)$ comparing treatment-2 $\left(2.94 \pm 0.17^{\mathrm{b}}\right)$.

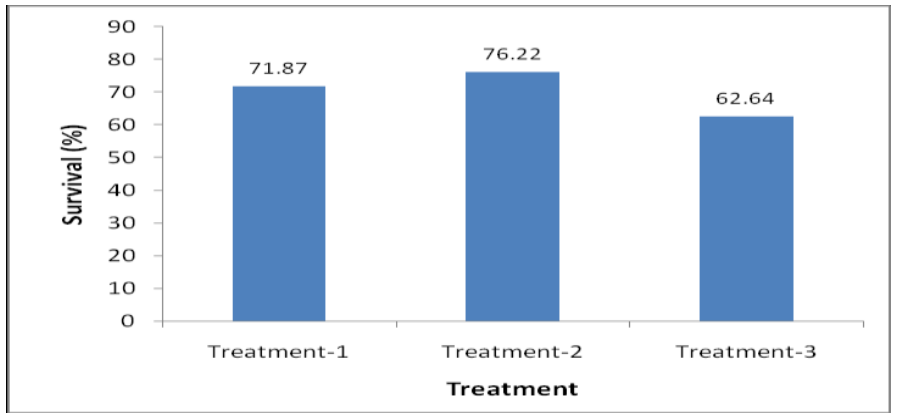

Figure 2. Survival of tilapia fry in different treatments.

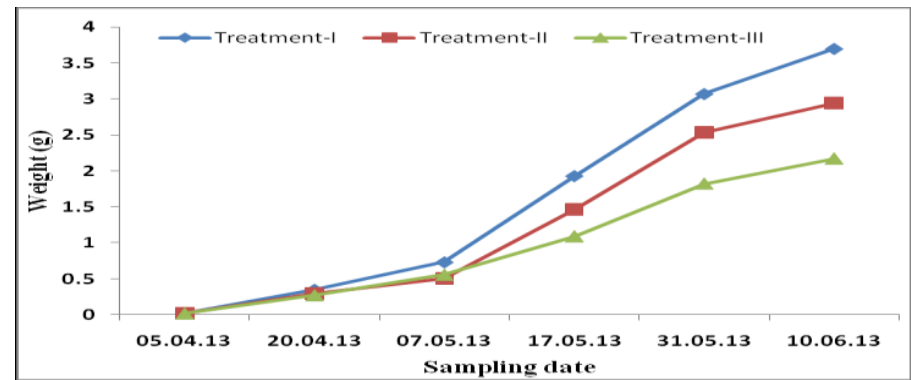

Figure 3. Monthly growth increment of tilapia fry in different treatments.

\subsection{Production and growth parameters of tilapia fry in different treatments}

The production and growth of tilapia fry can be measured by measuring different parameters such as individual stocking weight, individual harvesting weight, survival rate etc. and some factors such as FCR, SGR etc. All the growth parameters are presented in table 2.

Table 2: Comparisons of means $( \pm \mathrm{SD})$ of yield parameters of tilapia fry in different treatments during 51 days culture period.

\begin{tabular}{lccc}
\hline \multicolumn{1}{c}{ Parameters } & Treatment-I & Treatment-II & Treatment-III \\
\hline Individual stocking weight $(\mathrm{g})$ & 0.017 & 0.017 & 0.017 \\
Individual harvesting weight $(\mathrm{g})$ & $3.7 \pm 0.2^{\mathrm{a}}$ & $2.94 \pm 0.17^{\mathrm{b}}$ & $2.16 \pm 0.17^{\mathrm{c}}$ \\
Survival $(\%)$ & $71.87 \pm 5.92^{\mathrm{a}}$ & $76.22 \pm 3.76^{\mathrm{a}}$ & $62.64 \pm 2.47^{\mathrm{b}}$ \\
FCR & $1.14 \pm 0.038^{\mathrm{a}}$ & $1.35 \pm 0.015^{\mathrm{a}}$ & $2.24 \pm 0.258^{\mathrm{b}}$ \\
SGR $\left(\%\right.$ bw day $\left.{ }^{-1}\right)$ & $10.55 \pm 0.103^{\mathrm{a}}$ & $10.1 \pm 0.109^{\mathrm{b}}$ & $9.51 \pm 0.149^{\mathrm{c}}$ \\
Gross yield $\left(\mathrm{kg} \mathrm{m}^{-2}\right)$ & $1.99 \pm 0.07^{\mathrm{a}}$ & $2.01 \pm 0.02^{\mathrm{a}}$ & $1.43 \pm 0.16^{\mathrm{b}}$ \\
Net yield $\left(\mathrm{kg} \mathrm{m}^{-2}\right)$ & $1.98 \pm 0.07^{\mathrm{a}}$ & $2.00 \pm 0.02^{\mathrm{a}}$ & $1.41 \pm 0.16^{\mathrm{b}}$ \\
\hline
\end{tabular}

*Mean values followed by different superscript letters indicate significantly different $(\mathrm{P}<0.05)$.

Individual stocking weight in all the three treatments were $0.017 \mathrm{gm}$ while individual harvesting weight $(\mathrm{g})$ was found $3.7 \pm 0.2^{\mathrm{a}}$ in treatment I, $2.94 \pm 0.17^{\mathrm{b}}$ in treatment II and $2.16 \pm 0.17^{\mathrm{c}}$ in treatment III which is significantly different from each other. In case of FCR there is no significant difference between 
treatment I and treatment II but a significant difference in treatment III. But the differences of SGRs among the treatments were significant differ from each other, where the best in treatment I and least in treatment III consequently. Gross and net yield $\left(\mathrm{kg} \mathrm{m}^{-2}\right)$ in treatment I were $1.99 \pm 0.07^{\mathrm{a}}$ and $1.98 \pm 0.07^{\mathrm{a}}$ respectively whereas $2.01 \pm 0.02^{\mathrm{a}}$ and $2.00 \pm 0.02^{\mathrm{a}}$ in treatment II showed mostly similar with no significant difference but in treatment III the values showed significant differences with $1.43 \pm 0.16^{\mathrm{b}}$ and $1.41 \pm 0.16^{\mathrm{b}}$ respectively. The gross and net yields were found poor in treatment III comparatively.

3.4 Benefit-cost analysis in different treatments

Benefit-Cost Analysis estimates and totals up the equivalent money value of the benefits and costs whether they are worthwhile. Cost benefit analysis of three treatments showed expenditure and return of investment. Hapa, tilapia fry, feed and maintenance etc. costs were considered to calculate the total expenditure and return of expenditure was calculated from fingerling selling.

Table 3. Comparisons of economics (mean $\pm \mathrm{SD}$ ) among different treatments based on $1 \mathrm{~m}^{2}$ area of hapa.

\begin{tabular}{|c|c|c|c|c|}
\hline \multicolumn{2}{|r|}{ Items } & Treatment-I & Treatment-II & Treatment-III \\
\hline \multirow{4}{*}{ 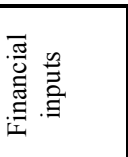 } & Hapa cost & 84 & 84 & 84 \\
\hline & Tilapia fry (Tk. 0.40 per fry) & 300 & 360 & 420 \\
\hline & Feed & 112 & 135 & 157 \\
\hline & Total costs & 496 & 579 & 660 \\
\hline \multirow{3}{*}{ 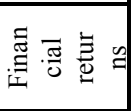 } & Total returns & $1078.08 \pm 88.75^{\mathrm{a}}$ & $1371.92 \pm 67.73^{b}$ & $1315.41 \pm 51.76^{b}$ \\
\hline & Net benefit & $582.45 \pm 88.75^{\mathrm{a}}$ & $793.12 \pm 67.73^{b}$ & $655.04 \pm 51.76^{\mathrm{ab}}$ \\
\hline & Benefit-cost Ratio (BCR) & $2.17: 1$ & $2.36: 1$ & $1.99: 1$ \\
\hline
\end{tabular}

*Different superscript letter indicated significant differences $(\mathrm{P}<0.05)$. Currencies are given in Bangladesh Taka, BDT (1 USD = 80 BDT).

Hapa making cost (Net, rope, bamboo, making cost), tilapia fry cost (Tk. 0.40 per fry) and feed are taken into consideration to calculate total cost which measured Tk. 496, 579 and 660 in treatment I, II and III respectively. This variation was due to the variations in number of fry used in different treatments. Net benefit in treatment I, II and III by selling the fingerling at Tk. 2.0 per fingerling were $582.45 \pm 88.75^{\mathrm{a}}, 793.12 \pm 67.73^{\mathrm{b}}$ and $655.04 \pm 51.76^{\mathrm{ab}}$ respectively. Net benefit showed significant difference between treatment I and treatment II with highest net profit in treatment II while in treatment III showed average net profit comparatively with no significant difference both with treatment I and II.

BCR in treatment I, II and III were finally estimated as 2.17:1, 2.36:1 and 1.99:1, respectively. The BCR showed that treatment II is the most favorable in relation to treatment I and III though treatment I found to be the most favorable for growth and production parameter because of lower stocking density as well.

\section{Discussions}

Tilapia fingerling production to ensure quality seed as a potential of aquaculture is used in this context to mean "Fish Culture which ${ }^{[3]}$ defined as the commercial rearing of fish done in conditions where all the basic means of production can be controlled within their respective limitations and from which producers' aim to obtain optimal economical results". The need for a regular source of fingerling supply in a commercial fish farm cannot be overemphasized as lack of it could reduce such a venture to a monumental waste and consequently discourage further financial investments in fish culture.

Huang and $\mathrm{Chiu}^{[4]}$ found that size variation, percentage and survival were found to be significantly affected by stocking density, but not for conditional factor. In the present study three treatments with different stocking density were evaluated and found significant difference among the growth parameter of them. It was found that treatment I showing stocking density of $750 / \mathrm{m}^{2}$ is most favorable and found all the growth parameter like FCR, SGR and survival rate best while considering the cost benefit ratio and growth parameters as well treatment I, comparatively treatment II found better for commercial aquaculture.

Hughes \& Behrends ${ }^{[5]}$ pointed out that the most important requirements for the advancement of tilapia culture are the development of systems for mass production of seed as the basis for every successful aquaculture practice. This paper therefore discusses optimal utilization of water in the drainage channel of a pond or reservoir for small scale commercial production of tilapia fry and fingerlings from the point of view of brood stock management as a modest investment option for small scale fish farmers. As in the haor region wild source of tilapia seed are mostly unavailable and culture in the area is fully depended on artificial hatchery produced seed. Besides most culture area in haor region are open water with flooded possibility which makes small fry of 24 days not suitable. A comparatively large size fingerling stocking in culture may reduced this problem at a great extent.

It seems that most of the activities in fish farming are performed by men, except for processing, which is done mainly by women. Similar observation has been made by Adebo and Alfred ${ }^{[6]}$ who reported that in Nigeria males are engaged in pond construction, pond installation and maintenance, disease control, fish sorting 
and fingerling production whereas females are involved in fish marketing, drying and smoking. According to Adebo and Alfred ${ }^{[6]}$ men are involved in the tedious aspects of tilapia production while women are mostly involved in activities that are related to their domestic duties in the households. During this study we observed that most of the women in haor region almost workless except household routine activities and child care and thus deprived. While women were involved in the research process they found happy with the work and curious to find a way of income. Though the male member of the family yet not prepared to let women involved in earning activities but it is always welcome to add some extra income in the family from any source. It can be assumed that if aquaculture can possible to be popular in the haor region women will easily able to add them with the process.

The amount of feed recommended is usually $5-10 \%$ of the body weight of the cultured fish ${ }^{[7]}$. However, in the present study area most fish farmers said that they do not weigh the fish cultured in the ponds, hence, do not feed their fish according to body weights, but provide feeds based on rough estimates of the feed required. This concurs with El-Sayed ${ }^{[8]}$ who reported that small-scale farmers manage their fish ponds by trial and error. According to $\mathrm{FAO}^{[9]}$ fish production under small-scale production system is low due to small pond size coupled with poor management. In this study favorable feeding rate and growth parameter analysis were done to seek most possible rate of stoking and consequent cost benefit ratio which will help small scale farmers to produce much profit with lowering cost as much. Wijkstrom and MacPherson ${ }^{[10]}$ have shown that small-scale fish farming with commercial orientation can be a very profitable activity and the wealth generated through fish farming may be a powerful tool for poverty reduction for rural poor involved in the sector.

Within recent years, some breakthroughs in certain aspects of aquaculture, which are of small scale nature, were achieved. One of these is the operation of shrimp/prawn hatcheries in some countries in the region ${ }^{[9]}$. In some countries such as Taiwan, Philippines and Thailand, there are several "backyard hatcheries" managed by experienced small farmers contributing significantly to the national total fish seed supply. In the small scale farm profit margin remains very low and sometimes because of poor management and lack of proper knowledge may lead to loss of them. So proper cost benefit analysis need to be consider for the small scale farmer. Stocking density is one of the factors that could potentially affect fish survival ${ }^{[11]}$ and production performance ${ }^{[12]}$, so it must be considered when determining the economic profitability of production systems $\mathrm{s}^{[13]}$. In the present study it was found that though the growth rate is found best in lowest stocking density by it is not commercially feasible because of low profit margin. The treatment with moderate stocking rate of $900 / \mathrm{m}^{2}$ found to be most profitable with Tk. $793.12 \pm 67.73^{\mathrm{b}}$ while in treatment I (stocking density $750 / \mathrm{m}^{2}$ ) and treatment III (stocking density $1050 / \mathrm{m}^{2}$ ) the net profit were $582.45 \pm 88.75^{\mathrm{a}}$ and $655.04 \pm \mathrm{SD} 51.76^{\text {ab }}$ respectively. As in the commercial production the increasing in stocking density also increase net profit with the same unit area and resources. But in small scale farming like tilapia fingerling production not only profit but also investment capability need to be take into consideration. The cost-benefit ratio found in this study shows that in treatment I, II and III the benefit-cost ratio were 2.17:1, 2.36:1 and 1.99:1, respectively which indicate a moderate stocking density of treatment II is most favorable. It was noticeable that though net profit in treatment III was higher than in treatment I but benefit cost ratio in treatment I is more favorable than treatment III. This is because of higher operating cost in treatment III than treatment I. So a farmer with low investment needs to follow the production plan of treatment II or treatment I whereas a farmer with high investment may choose either treatment II or treatment III. Other research studies with specifically to production of tilapia fingerling were not available to compare with this study. More works related to tilapia fingerling production and benefit cost measurement need to be evaluated for various types of farmer need to be initiated.

\section{Conclusion}

In the recent years aquaculture practices increasing rapidly throughout the world mostly in the developing countries like Bangladesh to reduce poverty and solving unemployment problem with self dependent program. With the increasing demand of tilapia seed various types small scale farming possibility introduced and tilapia fingerling production in hapa using swim up fry may be one of them. Because of higher growth rate and lower mortality of large sized fry it is much favorable among farmers and have good price in market. In the production plan of tilapia fingerling, stocking density plays an important role as increasing density to a certain may lead to increase in profit but also the production cost while lower density though ensure better growth may not favorable for commercial culture while very high density may hamper production and cost benefit ratio to greater extent. In conclusion it can be said that tilapia fingerling production in the haor region of Bangladesh can be a good venture for extra income for the marginal households as well as promotion of tilapia culture as food fish. Moreover involvement of women in this process could be a great initiative for women empowerment which will lead better livelihood of women as well as the households. 


\section{References}

[1]. G.M. Adebo, and S.D. Alfred, Economic analysis of contribution of tilapia production and marketing to gender empowerment in Ondo and Ekiti States, Nigeria. In: $8^{\text {th }}$ International Symposium on Tilapia in Aquaculture (ISTA8), Cairo, Egypt, October 12- 14, $2008,657-664$

[2]. M.H. Bahnasawy, T.E. Abdel-Baky, and G. Abd-Allah, Growth performance of Nile tilapia fingerlings raised in an earthen pond. Archives of Polish Fisheries, 11, 2003, 277-285.

[3]. N.R. Bromage, Broodstock management and seed quality-general considerations, Blackwell science, oxford, $1995,1-24$.

[4]. R.A.P.L.F. Carvalho, J.A.F. Lima, and A.L.N.Silva, Efeito da densidade de estocagem no desempenho do matrinxa, Brycon cephalus (Gunther, 1869), cultivado emtanques-rede no período de inverno. Boletim do Instituto de Pesca, v. 24, 1997, 177-185.

[5]. A.M. El-Sayed, Tilapia feed and feeding in semi-intensive culture systems. In: $8^{\text {th }}$ International Symposium on Tilapia in Aquaculture (ISTA8) Cairo, Egypt, October 12- 14, 2008. 717 - 723.

[6]. FAO, Food and Agriculture Organization of the United Nations. United Republic of Tanzania National Aquaculture sector overview. http:// www. fao. org/ fishery/ countrysector/ naso_tanzania/ en Accessed on $8^{\text {th }}$ October 2012.

[7]. T. Hecth, and W. Uys, Effect of density on the feeding and aggressive behavior in juvenile African catfish (Clarias gariepinus). South African Journal of Science, 93, 1997, 537-541.

[8]. E.D. Houde, Food concentration and stocking density effects on survival and growth of laboratory-reared larvae of Bay Anchovy Anchoa mitchilli and Lined sole Achirus lineatus. Marine Biology, 43, 1977, .333-341.

[9]. W. Huang, and T.S. Chiu, Effect of stocking density on survival, growth, size variation and production of tilapia fry. Aquaculture Research, 28, 1997, 165-173.

[10]. D.G. Hughes, and L.L. Behrends, Mass production of Tilapia nilotica seed in suspended net enclosures, in: Proceedings of International Symposium on Tilapia in Aquaculture. Nazareth, Israel, May 8 - 13, 1983.

[11]. M, Hussain, and A. Salam, Basic Service Delivery Advocacy: Review Report, Development Wheel (DEW), Dhaka, 2007.

[12]. D. Mires, A Technical Evaluation of Tilapia cultures, in Proceedings of International Symposium on Tilapia in Aquaculture, Nazareth, Israel, May 8 - 13, 1983.

[13]. U.N. Wijkstrom, and N.J. MacPherson, A cost benefit analysis of culture based fisheries development in small dams and dugouts. Field work paper 1: the economics of culture based fisheries. Field Document F1: TCP/GHA0051. FAO, Rome, Italy, 1990. 